\title{
Cyberbullying Prevention and Combating Strategies for High School Students in Jakarta
}

\author{
L Nurhadiyanto \\ Universitas Budi Luhur, Jakarta \\ lucky.nurhadiyanto@budiluhur.ac.id
}

\begin{abstract}
This research discuss about prevention and combating strategies of cyber bullying for high school students in Jakarta. It's so difficult to identify cyber bullying as an criminal act that considered a delinquent, deviance or crime. This situation makes the offender feels unguilty and claim that cyber bullying is no different with the ordinary thing. Although, Indonesia already have the Law of Electronic Information and Transactions (UU ITE) and Indonesia Panel Code (KUHP) which explicitly regulate cyber bullying but until now that activities still happening, even more frequent. Cyber bullying can not be separated from the involvement of perpetrator, victim and bystander. This is the basis of research to provide an alternative prevention and combating strategies of cyber bullying, especially for high school students in Jakarta. This research uses qualitative methods with focus group discussion and unstructured interview. Data for this research sourced form Harapan Ibu Islamic High School, Citra Alam High School, KPAI, Komnas PA, and Polri. The result is finding four characteristics of cyber bullying, which consist of the assumption that is not a crime; the domination of power; as an entertainment and enjoyment; and as a respond to the unproven truth
\end{abstract}

Keywords: Cyberbullying, Prevention, Combating, High school students

\section{INTRODUCTION}

The case of bullying has become an inseparable part of the diversity of life in Indonesia. Bullying seems to be a sub culture in Indonesian society. Bullying like another normal activity, actually done by everybody from various backgrounds. To do bullying doesn't recognize age, level education, gender, jobs or social status. Ironically, Indonesia's education becomes the big contributor for bullying case. International Center for Research on Women (ICRW) showed bullying data, that $84 \%$ of children in Indonesia involved bullying [1]. This figure shows that level of bullying in Indonesia is above the average compared to the trends in Asia which is at $70 \%$. Other fact showed that 1 of 3 female students and 1 of 4 male students in Indonesia have been the victim of such act. Komnas PA notes that there were 17 bullying cases that lead to the deatch of vitims in 2016. KPAI also revealed that bullying case tends to increase each year. In 2011, there were 2,178 cases. In 2012, there were 3,512 cases. This number increase in 2013 to 4,311 and in 2014 to 5,066 cases [2].

The advance technology then creates a new form of bullying which is the one which uses electronic media, known as cyber bullying. Cyber bullying becomes an issue that has received serious attention in Indonesia. Various cyber bullying case happened at the basic, intermediate, and higher education, as well as at all layers of society. The majority of this 
bullying act is done through social media. The survey by Association of Indonesian Internet Service Provider (APJII) in 2016 on internet users behavior in Indonesia showed that the social media is dominantly accessed through smartphone (as many as 89.9 million people or $67.8 \%$ ). The next devices used for social media access, in order, are personal computers (19.5 million people or $14.7 \%$ ), laptop (16.7 million people or $12.6 \%$ ), and tablet ( 5 million people or $3.8 \%$ ).

In accordance to that, the increasing rate of cyber bullying case cannot be separated from the type of internet contect accessed by the users. Social media becomes the content that mostly accessed, that covers $97.4 \%$ or by as many as 129.2 million users. The entertainment content is accessed by 128.4 million users, news content by 127.9 million users, educational content by 124.4 million users, commercial content by 123.5 million people, and public service by 121.5 million users. The main social media accessed by users in Indonesia are Facebook (71.6 million people or 54\%), Instagram (19.9 million people or $15 \%$ ), Youtube (14.5 million people or $11 \%)$, Google+ $(7.9$ million people or $6 \%)$, Twitter $(7.2$ million people or $5.5 \%$ ) and Linkedin (796 thousand people or $0.6 \%$ ).

The increase of cyber bullying case per year is related with the increase in numbers of internet user in Indonesia. The result of survey by APJII in 2016 has made classification the statistic of internet users in Indonesia from the total of her 256.2 million citizens. The data is as followed:

Statistical Data on Internet Users in Indonesia Based on Age in 2016

\begin{tabular}{|c|c|}
\hline Range of Age & Users (in million people) \\
\hline $25-29$ years & 24 million \\
\hline $35-39$ years & 24 million \\
\hline $30-34$ years & 23,3 million \\
\hline $20-24$ years & 22,3 million \\
\hline $40-44$ years & 16,9 million \\
\hline $15-19$ years & 12,5 million \\
\hline $45-49$ years & 7,2 million \\
\hline > 50 years & 1,5 million \\
\hline $10-14$ years & 768 hunderd \\
\hline
\end{tabular}

Source: Modified from APJII, 2016

At the range of age 10-14 years old, the number of internet users is as many as 768 thousand people. The number of users aging from 15-19 years old are significantly more comprising 12.5 million people. This significant loop is the highest compared to other ranges of age. The relation between range of age and level of education is also shown in the results of the survey conducted by APJII on internet users penetration in Indonesia based on field of work, which comprises of student of higher education $(89.7 \%)$, student $(69.8 \%)$, worker $(58.4 \%)$, housewife $(25.3 \%)$. Other field of work comprises only $6.7 \%$. The fact that students become the second biggest contributor shows the potential involvement in cyber bullying. That is why the author aims to research on the strategy to prevent and combat cyber bullying, especially the one that happens to highschool (SMA) students in Jakarta.

\section{RESEARCH METHOD}

This research uses qualitative approach to analyze cyber bullying. In criminology research, qualitative approach is able to show the number of real crimes that haven't been 
discovered. This is known as dark figure of crime. Coleman and Moynihan explains that dark figure of crime is something or crime that is not recorded or detected [3]. To face this problem, the information gathering should be done as comprehensive and indepth as possible. Therefore, qualitative method is conducted to study social and culture-related issues, individual behavior, and the process of decision making [4]. That makes qualitative approach able to describe life from different angle, depending on the perspective of each observer [5]. Beside that, the significant role of qualitative research is to understand phenomenon on human being and as the complementary from various disciplines of science [6].

The data collection is done through indepth interviewing of individuals and small groups, systematic observation of behaviour, and analysis of documentary data. beside that, this research also collects data from KPAI, Komnas PA, education institution, Polri, students, ebook, law and other regulations, journal, and articles on mass media. This reseach is conducted by collecting samples at high school located in Jakarta. Sampling was done at two locations, Harapan Ibu Islamic High School (SMA HI) and Citra Alam High School.

\section{RESULTS AND DISCUSSION}

SMA HI is located at Jl. H. Banan no. 1, Deplu Residence, Pondok Pinang, Kebayoran Lama, Jakarta Selatan. SMA HI is comprised of students from various background and condition. This school develop education model prioritizing on a harmony of national curriculum and Islamic based one. $100 \%$ of students has smartphone, and there is no prohibition to bring one to school. The ownership of smartphone is also supported with $80 \%$ of the students having account on social media.

SMA Citra Alam is located in Jalan Damai II no. 54, Ciganjur, Jakarta Selatan. SMA Citra Alam Ciganjur is also comprised of students with various background and condition, and is categorized as school that conducts inclusive education. This school develops education model that prioritizes socialization and problem solving with nature preservation character. $80 \%$ of the students has smartphone, but there is limitation on device use at school. From the total of smartphone users, $50 \%$ students has account in social media.

Cyber bullying in Indonesia involves a relative numerous dark figure of crime. This is shown from the number of report on cases related to children based on children protection cluster that are submitted to Indonesian Police Head Quarter and KPAI. The thing that makes it interesting is that the data at both institution do not classify cyber bullying into a single separated category. Referring to the data collected from Indonesian Police Head Quarter related to ITE in 2016, it was dominated with 708 cases on insult, 639 on web fraud, 309 on email fraud, 283 on telephone fraud, 138 on SMS fraud, from the total of 2,637 cases. Only 742 cases could be solved, equal to 1 in 4 reports. Among them, 185 are cases on web fraud, 166 on insult, and 110 on email fraud.

The percentage of penalizing ITE cases on blasphemy reaches $23.45 \%$. In this context, insulting, as included in cyber bullying, still became the type of case that happened most in 2016, and the level of solving the cases was still low. The following is the data statistic on ITE violation from Polri.

Data on ITE Cases from all Region Police in 2016

\begin{tabular}{|c|c|c|c|c|}
\hline \multirow{2}{*}{ No. } & \multirow{2}{*}{ Case } & \multicolumn{3}{|c|}{ January-Oktober 2016 } \\
\cline { 3 - 5 } & & CT & CC & \% \\
\hline 1. & Pornografi & 108 & 35 & 32.41 \\
\hline 2. & Pornografi Anak & 4 & 0 & 0.00 \\
\hline
\end{tabular}




\begin{tabular}{|c|c|c|c|c|}
\hline 3. & Perjudian Online & 23 & 17 & 73.91 \\
\hline 4. & Penghinaan & 708 & 166 & 23.45 \\
\hline 5. & Pemerasan & 19 & 3 & 15.79 \\
\hline 6. & Web Fraud & 639 & 185 & 28.95 \\
\hline 7. & Email Fraud & 309 & 110 & 35.60 \\
\hline 8. & Telp Fraud & 283 & 67 & 23.67 \\
\hline 9. & SMS Fraud & 138 & 55 & 39.86 \\
\hline 10. & Credit Card & 31 & 7 & 22.58 \\
\hline 11. & Menyebarkan Permusuhan & 44 & 11 & 25 \\
\hline 12. & Pengancaman & 88 & 19 & 21.59 \\
\hline 13. & Illegal Access & 115 & 28 & 24.35 \\
\hline 14. & Illegal Intersep & 12 & 4 & 33.33 \\
\hline 15. & Defacing & 44 & 10 & 22.73 \\
\hline 16. & DDOS/Defacing & 54 & 25 & 46.30 \\
\hline 17. & Identity Theft & 18 & 1 & 5.56 \\
\hline & Total & 2637 & 743 & \\
\hline
\end{tabular}

Source: Modified from Polri, 2016.

The level of teenager's understanding on cyber bullying is relatively low [7]. This happens due to the unawareness of both victims and perpetrators that they have actually been involved in cyber bullying activity. Even though it is difficult to identify the variety of cyber bullying, but the result of FGD done by the author discovers some forms of cyber bullying that have been experienced by the informants in both school. Those forms are:

i. Delivering message comprising insult or threat towards others;

ii. Dicussing someone that leads to insult to gain support in cornering others;

iii. Sending email, short message, SMS, MMS, picture, or video that involves tribe, religion, race, and adat (SARA) or sexual content to insult or offense others;

iv. Sending message to someone profile (flaming), through game online profile, or social media with content that insults or with purpose to "attack" the particular party; and

v. Sending message that hasn't been prooved valid related to an issue or particular party.

The character of cyber bullying in both school fulfill the element that cyber bullying does not require physical characteristic therefore, things related to SARA and both perpetrator and victims that tend to not knowing of each other. The characters of cyber bullying that shows from the object are as follows:

i. Student's expertise and understanding on technology is relatively good;

ii. The communication is mainly done indirectly, and the users oftenly use fake identity (anonymous)

iii. Perpetrator does not see the respond of the victim directly for some period of time (no face-to-face confront);

iv. The bystander could have double role-supporting the perpetrator in doing the act, at the same time, supporting the victim;

v. Message delivered through social media does potentially have huge impact;

vi. Message that has been received by other party tends to go viral (no safe haven).

Different to conventional bullying, the anonymousity, real time and massive character are tightly attached to cyber bullying [8]. First, anonymousity shows that the perpetrator does not have to reveal his or her identity, and anyone could be the perpetrator of cyber bullying. For the victim, the anonymousity means that it is difficult to identify the perpetrator. Second, 
real time character shows how cyber bullying could happen anytime and anywhere. Third, massive character shows that the society receive the content of cyber bullying. This means that the content does not exclusively reach the victim or his or her peer group, but also society in general. This research makes classification of cyber bullying happening in high school, which are:

i. Perpetrator does not have consciousness of being one. The act of cyber bullying is considered as merely an act of vengence for cyber bullying that has happened onto his or her friend. The motivation is merely giving back equal treatment of fellow victim.

ii. Perpetator understand very well of being one, in order to show power and control over others through his or her skill in using technology. Perpetator usually has been a victim of conventional bullying in the past. The source of problem is his or her experience as victim, and the fact that he or she is not even popular in real life. Therefore, the most effective way he or she chooses is through cyber world. This phenomenon is known as revenge of the nerds.

iii. Perpetrator understand very well of being one, and the act is done in group to dismiss the boredome or as a way to fulfill entertainment need.

iv. Perpetrator tends not to realize his or her act as cyber bullying. This phenomenon happened due to his or her habit to respond an issue without seriously think on the consequence.

Cyber bullying would never gain legitimacy from all society, even for defense or with offensive purpose [9]. The impat is so huge and surpassing the one of conventional bullying. The best way to avoid cyber bullying is to do prevention as early as possible. Therefore, the participation and role fulfillment of all stakeholders are important in formulating the strategy to prevent and combat cyber bullying [10]. The followings are the strategies for the one happening in high school:

a. Perpetrator

This research offers "THINK" approah as a formula to prevent cyber bullying. The first step is related to validity of distributed information. This is known as truth. The effort in checking the validity of an information is required so that the distributed information would not cover the content of bullying. The second step is to consider the aspect of usefulness of the information. This is known as helpful information. It would be better if the information that goes viral is helpful or useful for others. Next, the inspirational element of the information. This refers to a condition that shows the extent of how an information affects other's behavior or action. The information would not only helpful but also inspirational for society. The fourth step is to consider the importance of an information. This depends on the response of the receiver. This is also called with "necessary". The last step is to fulfill the requirement of "kindness". This refers to the conformity or compliance to local context (situation and condition).

b. Victim

The next prevention is targetted onto victim. Some of prevention could be done by the victim when being engaged to cyber bullying are:

i. Shifting the perception from being victim

Changing the perception as victim could shift the perpetrator concern away and reduce the guilt of the victim. This shows that thinking positive on things happening could set cyber bullying as something not important. Positioning oneself not as a victim could reduce the intensity of cyber bullying by perpetrator.

ii. Holding back the emotion in responding an offensive information 
The impact of viral information in cyber world is difficult to be restrained. Therefore, clarification on hoax is ineffective effort.

iii. Not responding exaggeratingly

Cyber bullying has tendency of increasing when the respond from the victim is in accordance with one that has been predicted and wanted by perpetrator.

c. Reaction from society

The analysis on this element is focused on the role of school and society. School has been chosen as the area of research object, while KPAI and Komnas PA are considered to represent the society element [11].

i. School

School becomes the potential arena of cyber bullying. Education institution that primarily becomes the frontliner of nation education, unfortunately has contribution in creating cyber bullying as sub culture in society. The factor of limited resources and weak regulation receives main attention in explaining the difficulties to discover cyber bullying in school. School as education entity (climate school) could have a big role in preventing and combating cyber bullying. School climate is a united ecology of various element in school that gives physical and psychological support to students (Notar, Padgett and Roden, 2013: 136). The support could help preventing cyber bullying. The main element in school that could intervene is the structure of leadership and students. The relationship between the management of class structure and peer-to-peer communication could prevent cyber bullying. This covers school surroundings, class management, teachers and students attitude. A positive and conducive school cllimate could perform as early prevention to cyber bullying. The strategy to prevent and combat that could be done by school are [12]:

- Giving an understanding and courage to talk about any involvement in cyber bullying;

- Setting rules and regulation that could prevent any potential cyber bullying;

- Creating easier mechanism in reporting the case;

- Giving an understanding on the positive impact of technology; and

- Holding a regular evaluation

ii. Society

The comprehension to put cyber bullying as part of bullying becomes the basic of what society could do. This research found three main elements that needs the participation of society (including family) giving support to the victim, investigating the case, as well as, embracing the perpetrator and giving sanction [13].

iii. Sanction

The effort to embrace the perpetrator and giving sanction is the last resort in facing widely spreaded and viral cyber bullying. This condition is worsen with the unavailability of legal solution towards the act and perpetrator of bullying, including cyber one. The ITE Law which specifically rules the penal act through electronic devices, is not that useful to handle the cyber bullying that has been done by minor. So far, the act of bullying and cyber bullying have only been punished with moral sanction and disciplinary act by school. Meanwhile, such bullying activity has created harm, and traumatized the victim. But, at the other hand, it is still considered as ineffective if the case of cyber bullying is directed to the penal aspect. The alternative strategy is to educate perpetrator and victim that cyber bullying is actually a crime.

\section{CONCLUSIONS}


Cyber bullying or bullying through electronic device is a part of deviance or crime as an impact of the advancement of technology. The deviance or crime is included into cyber crime study. The comprehension on cyber bullying as crime or deviance in sub culture needs to be socialized with ITE Law as reference. This is important to do due to frequent consideration of cyber bullying as an act that is not included as law breaching. The diversity of bystanding act surrounding cyber bullying creates the virality of distorted information. The impact is the bias of perpetrator and the tremendous trauma on the victim, especially from the psycho-social aspect. Cyber bullying affects massively on the victim. This condition is worsen with the character of cyber bullying such as anonymousity, timeless character, and the speed of virality. Therefore, cyber bullying does not only involve perpetrator, victim, but also the participation and response from society or witness (bystanders). The effort in searching for the right formula on strategy to prevent and combat cyber bullying hasn't been done together. The effort to rehabilitate the perpetrator becomes the main sanction. This is based on consideration that perpetrator and victim of cyber bullying is related one to another, in a way that the victim could become the perpetrator. The same happens in reverse, a perpetrator could become a victim.

\section{REFERENCES}

[1] Liputan 6, "Survei ICRW: 84\% Anak Indonesia Alami Kekerasan di Sekolah," 15 March 2015. [Online]. Available: http://news.liputan6.com/read/2191106/survei-icrw-84-anakindonesia-alami-kekerasan-di-sekolah.

[2] KPAI, "KPAI: Pelaku Kekerasan Terhadap Anak Tiap Tahun Meningkat," 14 Juni 2015. [Online]. Available: http://www.kpai.go.id/berita/kpai-pelaku-kekerasan-terhadap-anaktiap-tahun-meningkat/.

[3] L. Noaks and E. Wincup, Criminoogical Research: Understanding Qualitative Methods, vol. 39, London: Sage Publications, 2004, pp. 11.

[4] L. Kalof, M. Dan and T. Dietz, Essentials of Social Research, vol. III, Berkshire: Open University Press, 2008, pp. 79.

[5] Flick, U; von Kardorff, E; Steinke, Ines; A Companion to Qualitative Research, vol. 39, London: Sage Publications, 2004, pp. 3.

[6] Y. Darlington and D. Scott, Qualitative Research in Practice: Stories from the Field, vol. 3, Crows Nest: Allen \& Unwin, 2002, pp. 1-2.

[7] J. C. Molluzzo, J. Lawler and J. Manneh, "A Comprehensive Survey on Cyberbullying Perceptions at a Major Metropolitian University-Faculty Perspectives," in Proceedings of the Information Systems Educators Conference, 2012.

[8] C. E. Notar, S. Padgett and J. Roden, "Cyberbullying: A Review of the Literature," Universal Journal of Educational Research, vol. 1, no. 1, pp. 1-9, 2013.

[9] T. Beran and Q. Li, "The Relationship between Cyberbullying and School Bullying," ournal of Student Wellbeing, vol. 1, no. 2, pp. 15-33, Desember 2007.

[10] R. Slonje, P. K. Smith and A. Frisén, "The Nature of Cyberbullying, and Strategies for Prevention," Computers in Human Behavior, vol. 29, no. 1, pp. 26-32, April 2013.

[11] A. M. Sirait, Interviewee, Komisi Nasional Perlindungan Anak. [Interview]. 29 January 2016. 
[12] Susanto, Interviewee, Komisi Perlindungan Anak Indonesia. [Interview]. 2 February 2016.

[13] Amiruddin, Interviewee, Sekolah Menengah Atas Citra Alam. [Interview]. 14 July 2016. 